\title{
Small rise in written complaints for dental and GP practices
}

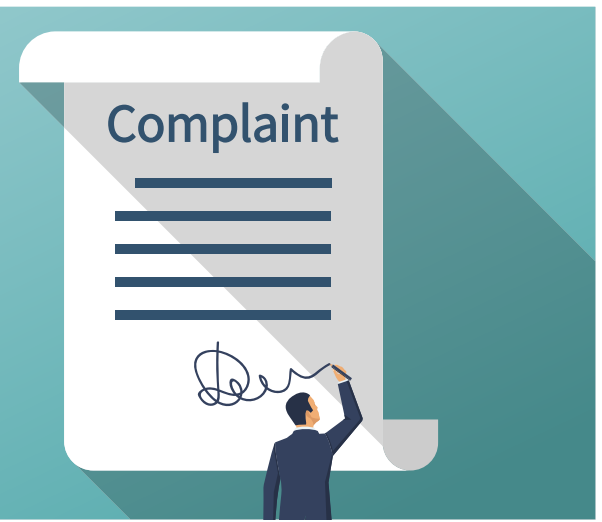

There was a small (4.5\%) rise in the number of written complaints being submitted to the NHS in England last year about services at dental and GP practices, according to figures released by NHS Digital on 6 September 2018. NHS England received 208,626 written complaints during 2017-18 - which equates to one complaint per 265 people in the overall England population - representing a $0.1 \%$ rise in complaints overall.
The report Data on written complaints in the NHS: 2017-18, ${ }^{1}$ includes the number of written complaints about both primary and secondary care and for the former, there was a $4.5 \%$ increase while complaints about secondary care fell by $3.3 \%$ since the previous year.

For primary care, which includes dental and GP practices, there were 94,637 written complaints in 2017-18 compared to 90,579 in 2016-17.

There were 113,989 complaints relating to secondary care, provided by hospitals and community health services in 2017-18 as compared to 117,836 in 2016-17.

NHS Digital said that a single written complaint could cover multiple subjects, service areas, and professions, meaning that the total number of written complaints involving a subject, service, or profession could be greater than the total number of written complaints. By service area, there were 96,700 complaints with $14.6 \%$ of these relating to 'Dental surgery' and $83.1 \%$ relating to 'GP surgery'.
By subject area, there were 111,046 complaints with $17.7 \%$ of these relating to 'clinical treatment' (18.2\% in 2016-17), $14.8 \%$ relating to 'communications' (16.0\% in 2016-17) and $11.3 \%$ relating to Staff Attitude/Behaviours/ Values (11.9\% in 2016-17).

By staff group, there were 98,300 complaints, with the largest proportion of $44.2 \%$ relating to practitioners (dentists or GPs) followed by administrative staff with $25 \%$.

Within the secondary care sector, complaints by profession showed that the medical profession received the highest number of written complaints with 65,737 - a $1.2 \%$ decrease from 2016-17 when there were 66,502 complaints, followed by the nursing profession, which received 35,873 written complaints - a 2.5\% decrease from 2016-17 when there were 36,784 .

1. NHS Digital. Data on Written Complaints in the NHS: 2017-18 (6 September 2018). Available at https://digital. nhs.uk/data-and-information/publications/statistical/ data-on-written-complaints-in-the-nhs/2017-18 (accessed on 11 September 2018). 